University of Nebraska - Lincoln

DigitalCommons@University of Nebraska - Lincoln

6-1999

Regime Type, Strategic Interaction, and the Diversionary Use of Force

Ross A. Miller

University of Nebraska - Lincoln, rmiller10@unl.edu

Follow this and additional works at: https://digitalcommons.unl.edu/poliscifacpub

Part of the Political Science Commons

Miller, Ross A., "Regime Type, Strategic Interaction, and the Diversionary Use of Force" (1999). Faculty Publications: Political Science. 54.

https://digitalcommons.unl.edu/poliscifacpub/54

This Article is brought to you for free and open access by the Political Science, Department of at DigitalCommons@University of Nebraska - Lincoln. It has been accepted for inclusion in Faculty Publications: Political Science by an authorized administrator of DigitalCommons@University of Nebraska - Lincoln. 
Published in the Journal of Conflict Resolution (June 1999) 43(3): 388-402. Copyright 1999, Sage. Used by permission.

\title{
Regime Type, Strategic Interaction, and the Diversionary Use of Force
}

\author{
Ross A. Miller \\ Department of Political Science \\ Santa Clara University
}

\begin{abstract}
This study explores the relative propensity of democratic and autocratic regimes to engage in diversionary behavior. Although previous research has focused on the willingness of leaders to engage in conflict, recent studies suggest an alternative explanation: the effect of strategic interaction opportunities. Previous studies suggest that even though democratic leaders may have an incentive to use foreign policy to manipulate domestic audiences, would-be adversaries limit their interaction opportunities. This article extends the analysis to a comparison of the behavior of democratic and autocratic regimes. Using three different indicators of the domestic political vulnerability of leaders - economic growth rates, protests, and rebellions the results indicate that democratic leaders are apparently more affected by strategic interaction opportunities than their autocratic counterparts.
\end{abstract}

Foiiowing the 1982 invasion of the Falkland Islands by Argentina, the New York Times reported that "Political leaders here. . . agree [that President Leopoldo Galtieri] has greatly enhanced his political power and stature." ${ }^{1}$ Similarly, in the 19971998 dispute between the United States and Iraq over the access of United Nations inspection teams to suspected nuclear, chemical, and biological weapons sites, some observers attributed the Clinton adminis tration's threat to use military force to domestic political problems. Charges of diversionary (or scapegoat) behavior on the part of leaders are certainly not new in the history of the United States or world history generally. Levy $(1989,263-265)$, for example, cites a number of qualitative studies that trace the international conflict behavior of nations to internal problems. Morgan and Bickers (1992, 26-27) suggest that "in fact, it might not be an overstatement to suggest that virtually every war since 1800 has been attributed, at least in part, to efforts of state leaders to deal with domestic problems."

Surprisingly, however, many of the attempts to assess the relationship quantitatively have concluded that this is most likely not the case, whereas other studies have produced mixed findings. There are a number of explanations for the lack of

${ }^{1}$ New York Times, April 6, 1982 (originally cited in Bueno de Mesquita and Siverson 1995, 841).

Author's note: I am grateful to Bob Jackman, Steve Nicholson, Randy Siverson, and Alastair Smith for helpful comments. Data are available upon request via e-mail: rmiller10@unl.edu (2012 affiliation, University of Nebraska-Lincoln). 
consistency between theory and empirical evidence. One of the more obvious, of course, is that the theory is simply wrong. Although their arguments are limited to research on U.S. presidents and the political use of force, Meernik and Waterman $(1996,577)$ contend that "it does not make theoretical sense to expect presidents will behave according to the logic of the diversionary model on a regular basis." Morgan and Bickers $(1992,28)$ point to a second possible explanation: all too often diversionary theory is treated as "a universal dictum of state behavior rather than as a partial explanation of some foreign policy decisions." Thus, given the myriad possible explanations for any decision to use military force, empirically it may be difficult to isolate the many cases in which the motivation to divert the public's attention from domestic political problems is the primary reason for the use of military force.

Leeds and Davis (1997) point to a third explanation: the effect of strategic interaction. Based on research by Smith (1996), Leeds and Davis argue that although democratic leaders may be willing to engage in diversionary behavior, would-be adversaries anticipate this willingness and limit their interactions with those leaders. Using a set of 18 industrial democracies, Leeds and Davis find no evidence of diversionary behavior.

The focus of this study is on the argument of Leeds and Davis (1997) that strategic interaction opportunities influence the behavior of leaders. This article builds and extends the research of Leeds and Davis in three ways. First, it evaluates the extent to which strategic interaction opportunities influence the behavior of democratic and autocratic leaders. Second, it distinguishes between states thatjoin an ongoing dispute and states that were original participants, since the former have greater opportunities than the latter. Finally, by building selection effects into the research design, the test for the influence of strategic interaction opportunities is made even more conservative.

\section{THEORETICAL LITERATURE}

The idea that leaders use foreign policy to manipulate domestic audiences is not new. In an often-cited quote, Bodin $(1955,168)$ suggests that "the best way of preserving a state, and guaranteeing it against sedition, rebellion, and civil war is to keep the subjects in amity one with another, and to this end, to find an enemy against whom they can make common cause." More recently, Wright $(1965,727)$ opined that war is a "necessary or convenient means ... to establish, maintain, or expand the power of a government, party, or class within a state."

Much of the theoretical literature is rooted in the in-group/out-group thesis of Simmel (1955), who contends that the cohesion of an in-group will increase in the presence of conflict with an out-group (see also Coser 1956; Stein 1976). Research in U.S. politics suggests that the theory applies at the national level as well as the group level.

Mueller (1970,1973), Brody and Page (1975), and MacKuen (1983) all report that popular support for presidents increases in response to foreign policy activity, a phenomenon that is often dubbed the "rally around the flag" effect. Assuming that leaders in power wish to retain power and that they will use domestic and foreign policies to manipulate domestic audiences, the contention that leaders engage in diversionary behavior appears reasonable (see also Leeds and Davis 1997; Meernik 1994; Meernik and Waterman 1996). 


\section{EMPIRICAL LITERATURE}

In perhaps the first quantitative study in this genre, Rummel (1963) found no relationship between the internal and external conflict behavior of 77 nations during the period from 1955 to 1957, and subsequent replications and cross-validations of his analysis generally support his conclusion (Burrowes and Spector 1973; Tanter 1966; Zinnes and Wilkenfeld 1971; Wilkenfeld 1972). Wilkenfeld's (1968) study is an exception. His research suggests that authoritarian regimes were more likely to go to war when faced with revolution at home, whereas polyarchic regimes were more likely to engage in conflict in light of domestic turmoil (see also Hazelwood 1973). Although Wilkenfeld provides some evidence of a link between internal and external conflict based on regime type, he does not offer a theoretical explanation for why this relationship should exist. Based on his review of this research, Levy $(1989,263)$ concludes that "although the results of some of the controlled studies are somewhat more encouraging, few of the findings indicate strong relationships." This may in part account for what appears to be a noticeable decrease in research on diversionary theory between 1975 and 1985.

Publication of Ostrom and Job's 1986 article on the determinants of the conflict behavior of U.S. presidents, however, brought about renewed interest in the subject. Of the 10 domestic and international variables included in their study, presidential approval ratings had the most pronounced effect on decisions to use force (Ostrom and Job 1986,557). Studies by James and Oneal (1991), Morgan and Bickers (1992), and DeRouen (1995) offer additional evidence that declining levels of support provide U.S. presidents with an incentive to pursue aggressive foreign policies. In a similar vein, Ostrom and Job (1986), James and Oneal (1991), and Wang (1996) found that changes in the "misery index" were linked to the use of force by U.S. presidents, and Stoll (1984) and Nincic (1990) concluded that the electoral cycle influences foreign policy decisions.

In stark contrast, Meernik (1994) and Meernik and Waterman (1996) question both the logic behind and the empirical support for diversionary behavior on the part of U.S. presidents. Leeds and Davis (1997) also question the idea that empirical evidence of diversionary behavior should exist. Drawing on an argument advanced by Smith (1996), Leeds and Davis contend that the vast majority of the quantitative analyses of diversionary theory fail to take selection effects into account. According to Smith, despite the effect that approval ratings, the economy, and the electoral cycle have on the willingness of leaders to engage in diversionary behavior, we may not see greater diversionary behavior on the part of democratic leaders empirically because other states will purposefully alter their behavior (where possible) to limit interaction opportunities during periods when democratic leaders appear to be politically vulnerable. In their study of 18 industrial democracies, Leeds and Davis $(1997,831)$ report that there is very little evidence of diversionary behavior on the part of leaders and attribute this finding to selection effects.

These results are similar to those reported by Miller (1995), who found no relationship between changes in economic growth and the dispute behavior of democratic leaders. Drawing on research by Bueno de Mesquita and Lalman (1992), Miller suggests that because democratic leaders generally anticipate higher domestic political costs for using force abroad than their authoritarian counterparts, 
they should be less prone to attempt to divert domestic attention by pursuing militarized foreign policies.

In contrast, Gelpi (1997) found a positive interactive effect between democracy and internal turmoil (measured in terms of protests and rebellions) and the level of force used in a crisis. Gelpi contends that the repressive capacities of autocratic leaders make them less willing than democratic leaders to pursue diversionary foreign policies when faced with domestic turmoil.

Setting aside the apparently contradictory empirical findings of Gelpi (1997) and Miller (1995), as Leeds and Davis (1997) point out, both of these approaches are somewhat limited on theoretical grounds because they do not take into account the role of strategic interaction in the formulation of their hypotheses (Leeds and Davis 1997, 820-22; see also Smith 1996). Gelpi (1997) and Miller (1995) focus on the willingness of leaders to undertake diversionary behavior, whereas Leeds and Davis (1997) and Smith (1996) focus on interaction opportunities.

This article provides an opportunity to compare the relative effect of strategic interaction opportunities on democratic and autocratic leaders. To address this question, an attempt has been made to make the test as conservative as possible by building selection effects into the research design. By using the militarized interstate dispute (MID) (Jones, Bremer, and Singer 1996) as the unit of analysis, I have isolated instances in which would-be diverters are already engaged in a dispute with another nation and have therefore selected themselves into a situation where diversionary actions would be easier to undertake than if they were not involved in a dispute. This provides an even more conservative test of the arguments of Smith (1996) and the empirical findings of Leeds and Davis (1997) that even though leaders may be willing to engage in diversionary behavior, other leaders alter their behavior to limit the opportunities of these diversionary-prone leaders. Given that the unit of analysis here is the dyadic dispute, it will be even more difficult for other states to limit conflict overall and diversionary behavior in particular.

The new MID data set (Jones, Bremer, and Singer 1996) also enables the control for possible diffusion effects that can influence strategic interaction opportunities (Siverson and Starr 1991). After all, World War II actually began as the GermanPolish War of 1939, and other states subsequently joined one side or the other. If we consider the foreign policy choice set of leaders at any given point of time, it appears reasonable to argue that even if leaders are willing to engage in diversionary behavior, they may be unable to do so because of a lack of opportunity (Smith 1996; Leeds and Davis 1997).

On the other hand, an ongoing conflict presents leaders with the choice of joining one side or the other; that is, it provides an opportunity. Therefore, the analyses below distinguish between the conflict behavior of the original participants of the dispute and those that joined the dispute.

Moreover, this analysis provides an opportunity to evaluate one possible explanation for the contrasting results of Gelpi (1997) and Miller (1995). Whereas Miller looked at the responses of targets of disputes, Gelpi's study focused on dispute initiators. To evaluate the possibility that the conflicting results reported above are simply a function of the different behavior of targets and initiators, the statistical research below performs separate analyses of the dispute behavior of initiators and targets. 


\section{RESEARCH DESIGN}

The dependent variable, force, is based on the codings used in the recently updated MID data set (Jones, Bremer, and Singer 1996; see also Gochman and Maoz 1984). In the analyses below, force takes the value of 0 for cases in which the dispute participant either did nothing or threatened or displayed force, 1 for instances in which minor levels of military force were used, and 2 for cases in which the use of force resulted in at least 1,000 battle deaths.

Three separate indicators of domestic political problems are used: changes in economic growth rates, levels of rebellion, and levels of protest. The first, economic growth, is based on the indicator used by Miller $(1995,770-71)$ and measured using the difference between the percentage rate of growth of per capita gross domestic product in the year prior to the dispute $(t-1)$ and the average growth rate during the previous 5 years $(t-2$ through $t-6){ }^{2}$ Fortunately, recently released data from Maddison (1995) provide a large temporal range in which to test the effects of changing economic growth rates on the dispute behavior of leaders. Maddison provides time series economic data for 49 countries for the period from 1820 to 1992 . The new MID data set covers the period from 1816 to 1992. Miller's (1995) study was restricted to a 20-year period (1956-1976), and thus employing the Maddison (1995) data provides an ideal way to cross-validate his findings across a much larger time period.

Gelpi $(1997,265)$ employed two different indicators of internal unrest, both of which were drawn from the World Handbook of Political and Social Indicators III (Taylor and Jodice 1986); both will be included in the analysis below. The first indicator, protest, includes "protest demonstrations of government policy, strikes or work stoppages aimed primarily at changing government policy and student stoppages of normal academic life in protest of government policy" (Gelpi 1997, 265). The second indicator, rebellion, includes "riots that are directed against government policies, protest demonstrations that turn into riots or combat with police, and armed attacks by organized groups against the government" (Gelpi 1997, 265). Both indicators are constructed by taking the average number of activities during the 3 months prior to the dispute. Because both of the indicators were badly skewed, ${ }^{3}$ it was necessary to transform them by taking the natural logarithm.

Based on the arguments put forth by Meernik (1994), Meernik and Waterman (1996), Miller (1995), and Gelpi (1997), two hypotheses will be tested.

Hypothesis 1: Democratic leaders are more likely than autocratic leaders to use force when faced with declining levels of support.

Hypothesis 2: Democratic leaders are less likely than autocratic leaders to use force when faced with declining levels of support.

Although the arguments of Leeds and Davis (1997) would appear to support the latter hypothesis, it is important to point out that they did not state directly whe-

${ }^{2}$ If the dispute occurred after July 1 , the measure is based on the growth rate in that year minus the average growth rate over the previous 5 years.

${ }^{3}$ For initiators, the variable rebellion had a mean of 1.5 and a skewness of 6.9 ; the corresponding figures for protests are 0.7 and 3.9. For targets, the rebellion measure had a mean of 1.5 and a skewness of 8.3. The figures for protests are 0.8 and 3.5 . 
ther selection effects should affect democratic leaders any differently than autocratic leaders.

Democracy is based on measures in the Polity III data set (Jaggers and Gurr 1996; see also Gurr, Jaggers, and Moore 1989), which is an updated and corrected version of Polity II. The measure is constructed by subtracting the autocracy measure from the democracy measure and, following Gelpi $(1997,266)$, resealing it so that it ranges from 0 to 20 . In the analyses below, the dispute behavior of more democratic states is compared with that of less democratic states. The cutoff point on the democracy variable is the median (about 12 on the 20-point scale). The democracy measure in Polity III is based on codings for four dimensions: the openness and competitiveness of executive recruitment, the competitiveness of participation, and legislative constraints on the executive. Autocracy includes all of the measures used to construct the democracy index, but it also includes the regulation of participation.

I also include a number of control variables. For ease of interpretation, these estimates are not reported in the tables below. ${ }^{4}$

\section{CONTROL VARIABLES}

Studies by Leng and Wheeler (1979), Leng (1983), Huth (1988), and Huth and Russett (1988) show that the bargaining strategies employed by nations involved in a dispute influence the outcome of that dispute. The use of bullying strategies (i.e. those characterized by high levels of hostility) by either dispute participant is systematically related to the escalation of that dispute to war. Based on this, I include the level of hostility of the initiator in the analysis of target behavior and the level of hostility of the target in the analysis of initiator behavior. Both of these measures are drawn from the new MID data set (Jones, Bremer, and Singer 1996).

A second control variable included in the statistical model is whether the initiator or target was a revisionist state. The justification for the incorporation of this variable is also based on studies by Leng and Wheeler (1979), Leng (1983), Huth (1988), and Huth and Russett (1988), since it seems reasonable to assume that revisionist states will be more likely to employ bullying strategies and, therefore, elicit a more hostile response from the other participant in the dispute, independent of the willingness of the target or initiator to escalate the dispute as a result of domestic political problems. This takes the value of 1 if the state is revisionist and 0 otherwise. As with the hostility variables, I distinguish between targets and initiators. The source for this variable is also the new MID data set (Jones, Bremer, and Singer 1996).

A final control variable is the relative power of the dispute participants. This measure is similar to that used by Gelpi (1997) and is based on the National Capabilities of States, 1816-1990, data set of the Correlates of War project (Jones, Bremer, and Singer 1996). It is based on the relative strength of the initiator and target according to an index composed of three indicators: the number of troops, military expenditures, and military expenditures per soldier. It is calculated by taking the percentage difference between the target and the initiator across these three dimensions.

\footnotetext{
${ }^{4}$ Estimates are available from the author upon request.
} 


\section{ANALYSIS}

Before preceding with a discussion of the estimates in the three tables below, a brief description of their structure is in order. Each of the three tables consists of 18 different statistical models, all of which include the control variables discussed above. As noted above, because of the large number of statistical models (54), presenting the estimates for the control variables would be unwieldy. ${ }^{5}$

${ }^{5}$ It should be noted that, as would be expected, the estimates for the control variables were not constant across the models reported in Tables 1 through 3. As indicated above (Note 4), these estimates are available upon request.

The key difference across the three tables is the indicator used to represent the domestic political vulnerability of the leader (economic growth rates in Table 1 and levels of rebellion and protest in Tables 2 and 3, respectively). The first column in each table represents estimates for democratic and nondemocratic states, whereas the second and third columns break down the original sample for less democratic and more democratic states. For the rows, I begin with a discussion of the estimates for all of the initiators in the data set. I then distinguish between the original initiators in the dispute (row 2) and those states thatjoined the side of the initiators (row 3). Immediately below the analysis of the behavior of the initiators, the results for the targets are presented.

The structure of the columns and rows is identical to that for the initiators, with the columns representing the estimates for democracies and nondemocracies (column 1), less democratic states (column 2), and more democratic states (column 3 ). The rows represent, respectively, all of the targets involved in the dispute followed by the original targets and the estimates for those states that joined the side of the targets.

Table 1 presents the estimates of an ordered probit analysis evaluating the effect of changing economic growth rates on the level of force used. As indicated above, the top portion of the table reports the estimates for the initiators of the dispute. As the first row indicates, for all initiators (democratic and nondemocratic states), the effect of economic growth rates on the level of force is negative and statistically significant (coefficient $=-1.75, z=2.25$ ). However, when we distinguish between the behavior of less and more democratic states, it appears that, on statistical grounds, only less democratic states engage in diversionary behavior to any significant degree (coefficient $=-4.12, z=3.27$ ). Although the sign of the coefficient estimate for more democratic states indicates a negative relationship $(-0.26)$, it is not statistically significant $(z=0.25)$.

These estimates provide preliminary support for Hypothesis 2-autocratic leaders should be more likely than democratic leaders to engage in diversionary behavior. Moving to the bottom portion of Table 1, we find a similar pattern for targets. For all the targets (democratic and autocratic), the estimate for economic growth is negative $(-1.79)$ and statistically significant $(z=2.30)$. When it is broken down by level of democracy, only the less democratic states engage in diversionary behavior to any significant degree (coefficient $=-2.20, z=2.24$ ).

When the results are disaggregated to distinguish between the original participants in the dispute and those states that joined the dispute (on the side of the 
Table 1

Economic Growth and the Political Use of Force

$\begin{array}{cccc} & \begin{array}{c}\text { Democracies and } \\ \text { Nondemocracies }\end{array} & \text { Low } & \text { Hemocracy } \\ \text { Initiators } & & & \text { Hemocracy } \\ \text { All initiators } & -1.75^{*} & -4.12^{*} & -0.26 \\ & (2.25) & (3.27) & (0.25) \\ N & 643 & 313 & 330 \\ \text { Original initiators } & 0.61 & -2.70 & 2.11 \\ & (0.59) & (1.50) & (1.57) \\ N & 453 & 246 & 207 \\ \text { Joiners } & -6.30^{*} & -6.95^{*} & -4.80 \\ N & (4.00) & (3.27) & (1.87) \\ N & 190 & 67 & 123 \\ \text { Targets } & & & -1.23 \\ \text { All targets } & -1.79^{*} & -2.20^{*} & (0.96) \\ N & (2.30) & (2.24) & 319 \\ N & 658 & 339 & -2.64 \\ \text { Original targets } & -1.43 & -0.42 & (1.55) \\ N & (1.17) & (0.23) & 124 \\ N & 384 & 150 & 0.66 \\ \text { Joiners } & -2.44^{*} & -2.88^{*} & (0.27) \\ N & (2.07) & (2.14) & 124\end{array}$

Note: The entries at the top of each cell are coefficients from an ordered probit analysis that includes the key independent variables and the control variables (the latter estimates are not reported). Entries in parentheses are z scores, with the number of cases in each model reported directly underneath.

*Significant at the 0.05 level (two-tailed).

target or the initiator), the results suggest that although autocratic leaders engage in diversionary behavior, the effect holds only for the joiners. Moreover, this effect holds for states that joined the side of the initiators (coefficient $=-6.95, z=3.27$ ) and those that joined the side of the targets (coefficient $=-2.88, z=2.14$ ). None of the estimates for the original participants in the dispute is statistically significant.

The estimates in Table 1 provide a couple of insights. First, they suggest little, if any, diversionary behavior on the part of democratic leaders, thereby providing support for Hypothesis 2 and the arguments of Leeds and Davis (1997), Meernik (1994), Meernik and Waterman (1996), and Miller (1995). They also suggest that autocratic leaders are opportunists-they are more likely to join a dispute at a high level of force when economic growth is declining. Moreover, it may also suggest additional evidence of the effect of strategic interaction on the behavior of states. Given that the effect of changing economic growth rates on the level of force used is not significant for either the democratic or the nondemocratic original participants, it may be the case that would-be diverters, in the absence of an ongoing dispute, are unable to use conflict involvement to manipulate domestic audiences because other states limit the interaction opportunities (i.e., they constrain the choice set of states 
that appear willing to engage in diversionary behavior). On the other hand, in light of an ongoing conflict, the dispute behavior of those autocratic states that join disputes appears to be significantly affected by domestic political conditions.

Table 2 evaluates the extent to which changes in the (natural logarithm of) level of rebellion influence dispute behavior. These estimates paint a similar, but not identical, picture as those in Table 1. Looking at the estimates for the initiators, we find that for all states, as the level of rebellion in the prior 3 months of the dispute increases, so does the probability that the leader will use high levels of force. Low levels of rebellion are associated with relatively low levels of force (coefficient $=$ $0.43, z=4.76$ ). When we break down these results by the level of democracy, it is once again apparent that less democratic states are more likely than autocratic states to engage in diversionary behavior (coefficient $=0.71, z=5.74$ ). The dispute behavior of democratic initiators is apparently unaffected by the level of rebellion (coefficient $=0.02, z=0.15$ ). In contrast to the results reported in Table 1 , however, the original initiators are affected by the level of rebellion (coefficient $=2.45, z$ $=4.30$ ). Although the estimate for the states that joined the side of the initiator(s) is positive (0.04) and therefore suggestive of diversionary behavior, it is not significant using conventional standards $(z=0.25)$.

The analysis of target behavior reveals results that are more consistent with those of Table 1. We find a significant relationship between level of rebellion and the level of force used for states that joined the side of the target. However, one of the key differences between the estimates reported earlier and the estimates here is that less democratic states are apparently unaffected by the level of rebellion. None of the estimates is statistically significant. This is consistent with Gelpi's (1997) argument that autocratic leaders can repress rebellions and, therefore, have no need to divert attention from internal problems. On the other hand, we find a significant negative effect for the democratic states (coefficient $=-0.44, z$ $=2.30$ ), and the effect for all of the democratic states is apparently driven by those that joined the side of the target (coefficient $=-0.91, z=2.84$ ). Morgan and Bickers $(1992,29)$ suggest a possible explanation for the restraining effect of rebellion on the behavior of democratic targets: "It may be that by the time domestic problems have reached the point of overt, high-level conflict it is too late to divert the public's attention with a foreign adventure." Although different in subtle ways from the estimates in Table 1, overall the results reported in Table 2 provide additional support for Hypothesis 2-democratic leaders are less likely than their autocratic counterparts to engage in diversionary behavior.

The results for the effect of the (natural logarithm of) protests on the conflict behavior of states are similar to those reported in Table 2. Protests have a restraining effect on both initiators and targets, but the effect is seen only for more democratic states. For the initiators, we note that only the coefficient for states with relatively high levels of democracy that joined the dispute is statistically significant (coefficient $=-1.38, z=2.63$ ), implying that the restraining effect of protests on dispute initiators is less pronounced than the effect of rebellion.

Moving down to the lower portion of Table 3, we see a consistent restraining effect across all types of democratic targets. In each case, the coefficient is negative and statistically significant. Although there is some evidence of a restraining effect of protests on less democratic leaders (coefficient $=-0.23$ ), the effect is not statistically significant $(z=0.86)$. 
Table 2

Rebellion and the Political Use of Force

$\begin{array}{lll}\text { Democracies and } & \text { Low } & \text { High } \\ \text { Nondemocracies } & \text { Democracy } & \text { Democracy }\end{array}$

Initiators

$\begin{array}{lccc}\text { All initiators } & 0.43^{*} & 0.71^{*} & 0.02 \\ & (4.76) & (5.74) & (0.15) \\ N & 416 & 259 & 157 \\ \text { Original initiators } & 1.37^{*} & 2.45^{*} & -0.18 \\ & (5.25) & (4.30) & (0.35) \\ N & 89 & 64 & 25 \\ \text { Joiners } & 0.03 & 0.04 & -0.01 \\ & (0.26) & (0.25) & (0.05) \\ N & 327 & 195 & 132 \\ \text { All targets } & & & \\ & -0.19^{*} & 0.10 & -0.44^{*} \\ N & (3.94) & (0.68) & (2.30) \\ \text { Original targets } & 415 & 212 & 204 \\ & -0.15 & 0.02 & -0.31 \\ N & (1.27) & (0.10) & (1.88) \\ \text { Joiners } & 314 & 154 & 160 \\ & -0.43^{*} & 0.28 & -0.91^{*} \\ N & (2.14) & (0.94) & (2.84) \\ & 101 & 58 & 43\end{array}$

Note: The entries at the top of each cell are coefficients from an ordered probit analysis that includes the key independent variables and the control variables (the latter estimates are not reported). Entries in parentheses are $\mathrm{z}$ scores, with the number of cases in each model reported directly underneath. *Significant at the 0.05 level (two-tailed).

\section{DISCUSSION}

The estimates reported in the tables above indicate general support for the arguments advanced by Leeds and Davis (1997) and Smith (1996). For democratic leaders, there appears to be no relationship between changing economic growth rates and dispute escalation. The same result holds for democratic initiators and the effect of levels of protest and rebellion. Democratic targets also are apparently restrained in their ability to escalate a dispute when faced with high levels of protest and rebellion.

Autocratic leaders appear to be less affected by strategic interac tion opportunities than their democratic counterparts. Overall, the results indicate more diversionary behavior empirically on the part of autocratic leaders than their democratic counterparts. Changing economic growth rates are negatively related to dispute escalation, and this holds for both autocratic initiators and targets. However, it is important to note that this relationship is significant only for autocratic leaders who join an ongoing dispute. This makes sense given the arguments of Leeds and Davis (1997) with regard to the importance of strategic interaction. An ongoing dispute presents an opportunity to engage in diversionary behavior. 


\begin{tabular}{cccc} 
& \multicolumn{2}{c}{ Table 3} & \\
& \multicolumn{1}{c}{ Protests and the Political Use of Force } & \\
\cline { 2 - 3 } & Democracies and & Low & High \\
Nondemocracies & Democracy & Democracy \\
Initiators & & & \\
All initiators & -0.01 & 0.35 & -0.13 \\
& $(0.07)$ & $(1.13)$ & $(0.93)$ \\
$N$ & 419 & 262 & 157 \\
Original initiators & 0.12 & 0.29 & 0.03 \\
$N$ & $(0.83)$ & $(0.77)$ & $(0.22)$ \\
Joiners & 330 & 198 & 132 \\
& -0.97 & 2.67 & $-1.38^{*}$ \\
$N$ & $(1.54)$ & $(1.62)$ & $(2.63)$ \\
Targets & 89 & 64 & 25 \\
All targets & & & \\
$N$ & $-0.38^{*}$ & -0.23 & $0.43^{*}$ \\
$N$ & $(3.12)$ & $(0.86)$ & $(2.99)$ \\
Original targets & 422 & 219 & 203 \\
$N$ & $-0.34^{*}$ & -0.30 & $-0.42^{*}$ \\
$N$ & $(2.52)$ & $(1.04)$ & $(2.57)$ \\
Joiners & 319 & 159 & 160 \\
$N$ & $-0.90^{*}$ & 0.91 & $-0.78^{*}$ \\
$N$ & $(2.67)$ & $(0.97)$ & $(1.97)$ \\
& 103 & 60 & 43
\end{tabular}

Note: The entries at the top of each cell are coefficients from an ordered probit analysis that includes the key independent variables and the control variables (the latter estimates are not reported). Entries in parentheses are z scores, with the number of cases in each model reported directly underneath.

*Significant at the 0.05 level (two-tailed).

On the other hand, the estimates for the effect of rebellions and protest suggest that there is no relationship between levels of protest and rebellion and dispute escalation for autocratic leaders. Of the 12 models used to test for a relationship between protest, rebellion, and escalation, only 2 indicate a significant, positive relationship. For the estimates with regard to protests and rebellion, there appears to be no relationship between levels of protest and rebellion and dispute escalation. This is consistent with Gelpi's (1997) argument that because autocratic leaders can repress protests and rebellion, they do not need to resort to diversionary behavior.

Neither Miller (1995) nor Gelpi (1997) anticipated the negative relationship between protest and rebellion and dispute escalation that was found for more democratic states. It may be the case, as Morgan and Bickers (1992) contend, that once the level of protest and rebellion reaches a certain level, a foreign diversion is unlikely to help a democratic leader. Moreover, as Leeds and Davis (1997) point out, would-be adversaries will limit the interaction opportunities of politically vulnerable leaders. Overall, the estimates reported in Tables 1 through 3 suggest that, empirically, democratic leaders do not appear to be particularly prone to engage 
in diversionary behavior. If Leeds and Davis (1997) and Smith (1996) are correct, this has less to do with the willingness of leaders to engage in diversionary behavior - as Meernik (1994), Meernik and Waterman (1996), and Miller (1995) contend - than it does with the opportunities to use foreign policy to manipulate domestic audiences. This, of course, does not mean that we should dismiss the importance of the willingness of leaders to engage in diversionary behavior. As Bueno de Mesquita and Siverson $(1995,842)$ point out, it is reasonable to "assume that political leaders are intent on maintaining themselves in power and [will] use the available tools of power and rules to accomplish this end."

A critical question remains: assuming that both democratic leaders and autocratic leaders face domestic pressures that may make diversionary foreign policies attractive, why does it appear that democratic leaders are less likely than autocratic leaders to use foreign policy to manipulate domestic political audiences?

One possible explanation for this centers on the idea that we know less about the political position of autocratic leaders than we do about the position of democratic leaders. The existence of opinion polls and the general openness of democratic societies allow would-be adversaries to estimate the willingness of democratic leaders more accurately than that of autocratic leaders to engage in diversionary behavior. Moreover, autocratic leaders depend on a much smaller ruling coalition to maintain power; therefore, to estimate accurately an autocratic leader's political position, it is necessary to understand levels of support within the ruling coalition, which can be a difficult undertaking in a relatively closed society (Bueno de Mesquita and Siverson 1997). The Bay of Pigs fiasco of 1961 is a telling example of the consequences of inaccurately estimating the security of an adversary's political position.

\section{CONCLUSION}

Generally, the results reported above are consistent with the growing body of research (theoretical and empirical) that suggests that democratic states do indeed behave differently than their autocratic counterparts. One potentially worthwhile avenue for future research is to explore in greater depth the ability of leaders to comprehend the political fortunes of would-be adversaries and their likely response to demands from other states, and to develop techniques that can improve upon our ability to model strategic interaction. Although progress has been made in identifying the effect of strategic interaction on international outcomes, to date many of the statistical techniques are less than optimal for modeling this phenomenon. Smith $(1998,699)$ sums up the problem nicely:

Suppose nation A, which is powerful, threatens nation B. Being powerful, and hence likely to win a fight, nation A will probably carry out its threats. Given this nation B sur- renders quickly. Although nation A is prepared to

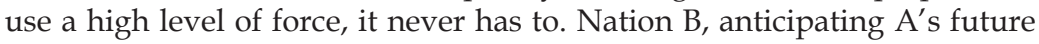
escalatory decisions, acquiesces immediately. Nation A never actually uses more than threats. [Therefore] ... A's potential to use violence causes nation $B$ to censor our observation of whether A uses higher levels of force.

In the case mentioned above, regardless of whether nation $\mathrm{A}$ is strong or weak 
relative to nation $B$, the outcome may be the same: no use of force. This provides a particularly difficult task for understanding the underlying causes of conflict if we limit ourselves to standard statistical techniques. Fortunately, research is under way that explicitly focuses on dealing with the interaction problem (Signorino 1997; Smith 1997, 1998).

\section{REFERENCES}

Bodin, Jean. 1955. Six Books of the Commonwealth. Translated by M. J. Tooley. Oxford, UK: Basil Blackwell.

Brody, Richard, and Benjamin Page. 1975. The impact of events on presidential popularity: the Johnson and Nixon administrations. In: Aaron Wildavsky, editor, Perspectives on the Presidency, p. 136-147. Boston: Little, Brown.

Bueno de Mesquita, Bruce, and David Lalman. 1992. War and Reason. New Haven, Conn.: Yale University Press.

Bueno de Mesquita, Bruce, and Randolph M. Siverson. 1995. War and the survival of political leaders: a comparative study of regime types and political accountability. American Political Science Review 89: 841-855.

Bueno de Mesquita, Bruce, and Randolph M. Siverson. 1997. Inside-out: a theory of domestic political institutions and issues of international conflict. Paper prepared for the annual meeting of the International Studies Association, March, Toronto.

Burrowes, R., and B. Spector. 1973. The strength and direction of relationships between domestic and external conflict and cooperation. In: J. Wilkenfeld, editor, Conflict Behavior and Linkage Politics, p. 294-321. New York: David McKay.

Coser, L. 1956. The Function of Social Conflict. New York: Free Press.

DeRouen, Karl R. 1995. The indirect link: politics, the economy, and the use of force. Journal of Conflict Resolution 39: 671-695.

Gelpi, Christopher. 1997. Democratic diversions: government structure and the externalization of domestic conflict. Journal of Conflict Resolution 41: 255-282.

Gochman, Charles S., and Zeev Maoz. 1984. Militarized interstate disputes, 18161976: procedures, patterns and insights. Journal of Conflict Resolution 28: 586615.

Gurr, Ted Robert, Keith Jaggers, and Will Moore. 1989. Polity II Handbook. Boulder: University of Colorado Press.

Hazelwood, Leo A. 1973. Externalizing systemic stress: international conflict as adaptive behavior. In: J. Wilkenfeld, editor, Conflict Behavior and Linkage Politics, p. 148-190. New York: David McKay.

Huth, Paul. 1988. Extended Deterrence and the Outbreak of War. New Haven, Conn.: Yale University Press.

Huth, Paul, and Bruce M. Russett. 1988. Deterrence failure and crisis escalation. International Studies Quarterly 32: 29-46.

Jaggers, Keith, and Ted Robert Gurr, producers. 1996. Polity III: Regime Change and Political Authority, 1800-1994 [computer file]. Study 6695, 2nd ICPSR version. Ann Arbor, Mich.: Inter-University Consortium for Political and Social Research [distributor].

James, Patrick, and John Oneal. 1991. The influence of domestic and international politics on the president's use of force. Journal of Conflict Resolution 35: 307-332. 
Jones, Daniel M., Stuart A. Bremer, and J. David Singer. 1996. Militarized interstate disputes, 1816-1992: rationale, coding rules, and empirical patterns. ConflictManagementand Peace Science 15: 163-213.

Leeds, Brett Ashley, and David R. Davis. 1997. Domestic political vulnerability and international disputes. Journal of Conflict Resolution 41: 814-835.

Leng, Russell J. 1983. When will they ever learn? Coercive bargaining in recurrent crises. Journal of Conflict Resolution 27: 379-420.

Leng, Russell J., and Hugh G. Wheeler. 1979. Influence strategies, success, and war. Journal of Conflict Resolution 23: 655-684.

Levy, Jack. 1989. The diversionary theory of war. In: M. Midlarsky, editor, Handbook of War Studies, p. 259-288. Boston: Unwin Hyman.

MacKuen, M. 1983. Political drama, economic conditions, and the dynamics of presidential popularity. American Journal of Political Science 27: 165-192.

Maddison, Angus. 1995. Monitoring the World Economy, 1820-1992. Paris: Organization for Economic Cooperation and Development.

Meernik, James. 1994. Presidential decision making and the political use of military force. International Studies Quarterly 38: 121-138.

Meernik, James, and Peter Waterman. 1996. The myth of the diversionary use of force by American presidents. Political Research Quarterly 49: 573-590.

Miller, Ross A. 1995. Domestic structures and the diversionary use of force. American Journal of Political Science 39: 760-785.

Morgan, T. Clifton, and Kenneth N. Bickers. 1992. Domestic discontent and the external use of force. Journal of Conflict Resolution 36: 25-52.

Mueller, John. 1970. Presidential popularity from Truman to Johnson. American Political Science Review 64: 18-34.

Mueller, John. 1973. War, Presidents, and Public Opinion. New York: Wiley.

Nincic, Miroslav. 1990. U.S. Soviet policy and the electoral connection. World Politics 42: 370-396.

Ostrom, Charles, and Brian Job. 1986. The president and the political use of force. American Political Science Review 80: 541-566.

Rummel, Rudolph J. 1963. Dimensions of conflict behavior within and between nations. Yearbook of the Societyfor General Systems 8: 1-50.

Signorino, Curtis S. 1997. Estimation and strategic interaction in discrete choice models of international conflict. Unpublished manuscript, Harvard University and University of Rochester.

Simmel, G. 1955. Conflict and the Web of Group Affiliations. Glencoe, Ill.: Free Press. Siverson, Randolph M., and Harvey Starr. 1991. The Diffusion of War: A Study of Opportunity and Willingness. Ann Arbor: University of Michigan Press.

Smith, Alastair. 1996. Diversionary foreign policy in democratic systems. International Studies Quarterly 40: 133-153.

Smith, Alastair. 1997. Testing theories involving strategic choice: the example of crisis escalation. Unpublished manuscript, Washington University.

Smith, Alastair. 1998. A summary of political selection: the effect of strategic choice on the escalation of international crises. American Journal of Political Science 42: 698-701.

Stein, Arthur A. 1976. Conflict and cohesion: A review of the literature. Journal of Conflict Resolution 20: 143-165. 
Stoll, Richard J. 1984. The guns of November: Presidential reelections and the use of force, 1947-82. Journal of Conflict Resolution 28: 231-246.

Tanter, Raymond. 1966. Dimensions of conflict behavior within and between nations, 1958-1960. Journal of Conflict Resolution 10: 41-64.

Taylor, Charles L., and David Jodice. 1986. World Handbook of Political and Social Indicators III, 1948-82 [computer file]. Compiled by Charles Lewis Taylor. 2nd ICPSR ed. Ann Arbor, Mich.: Inter-University Consortium for Political and Social Research.

Wilkenfeld, Jonathan. 1968. Domestic and foreign conflict behavior of nations. Journal of Peace Research 1: 56-69.

Wilkenfeld, Jonathan. 1972. Models for the analysis of foreign conflict behavior of states. In: B. Russett, editor, Peace, War, and Numbers, p. 275-298. Beverly Hills, Calif.: Sage.

Wright, Quincy. 1965. A Study of War. Chicago: University of Chicago Press.

Zinnes, Dina, and Jonathan Wilkenfeld. 1971. An analysis of foreign conflict behavior of nations. In: W. Hanreider, editor, Comparative Foreign Policy, p. 167213. New York: David McKay. 